University at Buffalo School of Law

Digital Commons @ University at Buffalo School of Law

\title{
The Incompatible Treatment of Majorities in Election Law and Deliberative Democracy
}

James A. Gardner

University at Buffalo School of Law

Follow this and additional works at: https://digitalcommons.law.buffalo.edu/journal_articles

Part of the American Politics Commons, Constitutional Law Commons, and the Election Law Commons

\section{Recommended Citation}

James A. Gardner, The Incompatible Treatment of Majorities in Election Law and Deliberative Democracy, 12 Elec. L.J. 468 (2013).

Available at: https://digitalcommons.law.buffalo.edu/journal_articles/202

\section{C) ${ }_{\text {COPYRIGHT }}^{\text {N }}$}

This Article is brought to you for free and open access by the Faculty Scholarship at Digital Commons @ University at Buffalo School of Law. It has been accepted for inclusion in Journal Articles by an authorized administrator of Digital Commons @ University at Buffalo School of Law. For more information, please contact lawscholar@buffalo.edu. 


\title{
The Incompatible Treatment of Majorities in Election Law and Deliberative Democracy
}

\author{
James A. Gardner
}

\begin{abstract}
Deliberative democracy offers a distinctive and appealing conception of political life, but is it one that might be called into service to guide actual reform of existing American election law? This possibility seems remote because American election law and deliberative democracy are built around different priorities and theoretical premises. A foundational area of disagreement lies in the treatment of majorities. Election law is structured, at both the legislative and constitutional levels, so as to privilege majorities and systematically to magnify their power, whereas deliberative democracy aims at privileging minorities (or at least de-privileging majorities). The main purpose of the election law now on the books is to narrow electoral choice; it seeks at every step to exclude views from public conversation in a process of winnowing out those that command the support only of a minority. Deliberative democracy's goals and methods, in contrast, stress at every turn the inclusion of many voices, especially those of minorities and of the socially and politically excluded. Deliberative democracy's goal is not to identify a majority entitled to rule, but to destabilize and transform that majority by exposing its members to opinions and beliefs they do not already hold. Election law resists such a process. As a result, any attempt to incorporate principles of deliberative democracy into the design of election law faces serious and deeply entrenched obstacles.

On the other hand, deliberative democracy may well have a valuable role to play by helping to make the process of public opinion formation outside election campaigns fairer, better informed, and more deliberative. This is in any case where most of the real action takes place: public political opinion is not formed to any significant degree during the brief season of elections and their formal campaigns-within, that is to say, the small slice of political life that falls within the domain of election law proper. On the contrary, public political opinion is formed continually, and therefore mainly between elections. Consequently, if the process of public political opinion formation falls short of deliberative ideals, deliberative democracy can do the most good by addressing itself to the arena of quotidian, non-electoral politics.
\end{abstract}

James A. Gardner is the Bridget and Thomas Black SUNY Distinguished Professor at SUNY Buffalo Law School, The State University of New York, in Buffalo, NY. Portions of this article draw heavily on James A. Gardner, What Are Campaigns For? The Role of Persuasion in Electoral Law and Politics (Oxford University Press 2009). I thank Oxford University Press, USA, for permission to reuse passages from that work. A draft of this article was originally presented at the Straus Institute for the Advanced Study of Law and Justice, New York University, in conjunction with a symposium on The Law of Deliberative Democracy, April 5-6, 2013.
$\mathbf{F}$ OR A QUARTER CENTURY OR MORE, theories of deliberative democracy have laid upon the intellectual table a distinctive and appealing conception of political life. In their emphatic rejection of economic and minimalist accounts of democracy, and in their insistence on an ideal of deep and universal political engagement, theories of deliberative democracy are attractive philosophically. In their account of democracy as an arena of reasoned, respectful, and inclusive talk among equals, theories of deliberative democracy are appealing politically and sociologically. In their sophisticated affirmation 
of a nearly ubiquitous popular critique holding contemporary political discourse to be coarse, uninformed, and unsatisfying, theories of deliberative democracy are well attuned to public opinion.

Despite these virtues, however, deliberative democracy has long been criticized as so unrealistic in its demands and so utopian in its ideals as to render it essentially useless as a guide to actual reform in existing political societies. ${ }^{1}$ This article explores that critique from the point of view of American election law by asking whether, and if so how, principles of deliberative democracy might be called into service to guide reform of the law regulating elections and campaigns for the purpose of moving it closer to the deliberative ideal. I conclude that this possibility is remote for a basic reason: American election law and deliberative democracy are founded on different priorities, assumptions, and theoretical premises, and as a result they are largely incompatible.

The basic problem is simple and foundational: American election law is structured, at both the legislative and constitutional levels, so as to privilege majorities and systematically to magnify their power, whereas deliberative democracy aims at privileging minorities (or at least de-privileging majorities). The main purpose of the election law now on the books in the United States is to narrow electoral choice-and with it the scope of public discussion - to a small number of candidates and ideas that enjoy significant popular support. At every step, election law seeks to exclude views from public conversation in a process of winnowing out those that command the support only of a minority. In so doing, the opinions and preferences of a majority acquire at each stage ever more power and significance until the final vote, a mechanism designed to hand government power to the prevailing majority.

Deliberative democracy's goals and methods, in contrast, stress at every turn the inclusion of many voices, especially those of minorities and of the socially and politically excluded. Deliberative democracy cultivates serious, open-minded consideration of and respectful attention to minority views, and it celebrates the attempt to reach agreement not among the like-minded, no matter how numerous, but to reach agreement out of diversity, a diversity that it contends should be carefully and respectfully nurtured. Deliberative democracy's goal is not to identify a majority entitled to rule, but to destabilize and transform that majority by exposing its members to opinions and beliefs they do not already hold.

Because of this stark disjunction, any attempt to incorporate principles of deliberative democracy into the design of election law faces serious and deeply entrenched obstacles. Most obviously, altering the law to operationalize deliberative democracy would require a very substantial degree of institutional change; indeed, it would require a virtually complete reorientation of legal institutions, from top to bottom. Moreover, it is far from clear that reconfiguring electoral laws and institutions in this way would work an improvement. There are good reasons for election law to aspire to little more than taking an accurate snapshot of exogenous public opinion. In a democratic society of any size, that by itself is an enormous, difficult, and complex undertaking. Complicating it by regulating or establishing standards for the quality of public opinion from which voting proceeds may be more than any feasible set of electoral institutions can handle.

Nevertheless, deliberative democracy may well have a valuable role to play, but in a different way. Even if principles of deliberative democracy might not readily find a home within the formal institutional structure of elections and campaigns, such principles may prove useful in politics by helping to make the process of public opinion formation outside campaigns fairer, better informed, and more deliberative. In fact, I shall argue, this is where the real action takes place because public political opinion is not formed to any significant degree during the brief season of elections and their formal campaigns - within, that is to say, that portion of political life that falls within the domain of election law proper. On the contrary, public political opinion is formed continually, which is to say mainly between elections. Consequently, if there are defects in how public political opinion presently is formed-and I concur with deliberative democrats that such defects are legion - then deliberative democracy can do the

\footnotetext{
${ }^{1}$ E.g., Ian Shapiro, Enough of Deliberation: Politics is about Interests and Power, in Deliberative Politics: Essays on Democracy and Disagreement (Stephen Macedo, ed. 1999); Michael Walzer, Deliberation, and What Else?, in Macedo, supra, at 68; Adam Przeworski, Deliberation and Ideological Domination, in Deliberative Democracy (Jon Elster, ed. 1998); John Ferejohn, Instituting Deliberative Democracy, in Nomos XLII: Designing Democratic Institutions (Ian Shapiro and Stephen Macedo, eds. 2000); James Johnson, Arguing for Deliberation: Some Skeptical Considerations, in Elster, supra.
} 
most good by addressing itself to the arena of quotidian, non-electoral politics.

At some level, I suspect, proponents of deliberative democracy seem to realize this, for this is exactly where they have thus far focused most of their efforts. As scholars and activists have turned increasingly to the question of how a regime of deliberative democracy might be implemented in the real world, their work has largely bypassed elections altogether and tended to focus on ways in which citizens might deliberatively exert influence directly on policy decisions made by governments already in place. This, I think, is the right venue for deliberative democrats to ply their trade and the one in which their work can do the most good.

The balance of this article is organized as follows. Part I reviews the basic tenets of deliberative democracy and describes its thoroughgoing commitment to elevating the role of minorities in democratic politics. Part II considers several of the major structures of American election law, including the prevailing legal regimes of ballot access, campaign speech, public financing, and party competition. I argue that, notwithstanding a considerable amount of constitutional rhetoric celebrating electoral deliberation, these institutions operate unrelentingly to privilege and to magnify the power of political majorities, and that they very likely contribute in practice to the exclusion of minority views from public electoral discourse.

Part III argues that none of this should worry deliberative democrats because their work is more usefully deployed to deal with a much more serious problem - the problem of majoritarian bias in public opinion formation outside the highly regulated and artificially constructed arena of formal elections. Social science research confirms what some deliberative theorists have long maintained: the public opinion formation that really counts occurs every day in the overwhelmingly non-electoral setting of daily life and ordinary political experience. It is here that majoritarian privilege can and should be resisted, and deliberative democracy has something useful to say about how that goal might be accomplished.

\section{DELIBERATIVE DEMOCRACY'S PRIVILEGING OF MINORITY VIEWS}

Any attempt to characterize deliberative democracy as a theoretical construct must begin with a frank recognition that pinning down exactly what it prescribes can at times be frustratingly difficult. One difficulty is that deliberative democracy contains two major and very different strands of thought. One strand consists of a strong version based on a distinctive and highly prescriptive conception of democratic legitimacy. The main tenet of this strand of thought is that law is legitimately binding only insofar as it emerges from the deliberatively formed will of all those who will be bound by it. ${ }^{2}$ This version has received a good deal of criticism on the ground that it is infeasible on a large scale because it appears to require both universal deliberation and consensus, or a strong approach toward both. A weaker version, fully compatible with standard conceptions of liberal democracy, simply advocates more deliberative and better quality public opinion formation. ${ }^{3}$ The point in this formulation seems to be the unobjectionable one that, however a society chooses to structure its democratic processes, it can always benefit from a democratic public that is better informed, more open-minded toward and tolerant of dissent, and more involved in the formulation of public policy.

A second difficulty in attributing particular beliefs and positions to deliberative democracy is that, at least from the point of view of interested outsiders, it has been a frustratingly moving target as it has responded to a series of internal and external critiques. In particular, the heart of the theory-its core conception of deliberation-has been modified frequently, often in ways that make it hard to distinguish what the theory prescribes from what existing democratic societies already do. Whereas originally deliberation was understood to be a very specific and tightly constrained activity conducted under demanding ethical rules of intense engagement, respectful listening, sincere open-mindedness, equality of power, noncoerciveness, non-instrumental

\footnotetext{
${ }^{2}$ Joshua Cohen, Democracy and Liberty, in Deliberative Democracy (Jon Elster, ed. 1998); Dennis Thompson, Just Elections: Creating a Fair Electoral Process in the United States 191 (2002); John S. Dryzek, Foundations and Frontiers of Deliberative Governance 3, 21 (2010).

${ }_{3}^{3}$ James S. Fishkin, The Voice of the People: Public Opinion and Democracy (expanded ed. 1997); Robert E. Goodin, Reflective Democracy (2003); Robert E. Goodin, Innovating Democracy: Democratic Theory and Practice after the Deliberative Turn (2008); Michael X. Delli Carpini, Fay Lomax Cook, and Lawrence R. Jacobs, Public Deliberation, Discursive Participation, and Citizen Engagement, 7 Ann. Rev. Pol. Sci. 315 (2004).
} 
treatment of interlocutors, and so forth, this ideal has gradually been significantly diluted. Today, it appears that the concept of deliberation is capacious enough to include ordinary talk, non-political talk, appeals to emotion, bargaining, negotiation, power tactics, the use of coercion, exploitation of inequality, and even the deployment of such distinctly nondeliberative tactics as heckling and protest. ${ }^{4}$

Despite this flux, it seems fair to suggest that deliberative democrats have nevertheless advanced some relatively stable and consistent requirements concerning what kind of talk, and in what circumstances, may count as deliberation for purposes of the theory. In most theories, for example, processes of deliberation must be inclusive so that deliberators may consider the greatest variety of viewpoints, a practice said both to improve the quality of decision making and to ensure that all who will be bound by democratic decisions have a voice in making them. ${ }^{5}$ Deliberation also must occur pursuant to fair procedures that guarantee equality so that deliberations are not inappropriately dominated by the powerful. ${ }^{6}$

${ }^{4}$ Jane Mansbridge, Everyday Talk in the Deliberative System, in Deliberative Politics: Essays on Democracy and Disagreement, supra note 1; Robert E. Goodin, Sequencing Deliberative Moments, 40 Acta Political 182 (2005); Jane Mansbridge, James Bohman, Simone Chambers, Thomas Christiano, Archon Fung, John Parkinson, Dennis F. Thompson, and Mark E. Warren, A Systemic Approach to Deliberative Democracy, in Deliberative Systems: Deliberative Democracy at the Large Scale (John Parkinson and Jane Mansbridge, eds. 2012); Jane Mansbridge, "Deliberative Democracy" or "Democratic Deliberation?" in Deliberation, Participation and Democracy: Can the People Govern? (Shawn W. Rosenberg, ed. 2007); Iris Marion Young, Activist Challenges to Deliberative Democracy, 29 Pol. Theory, 670 (2001). See also James Bohman, The Coming of Age of Deliberative Democracy, 6 J. Pol. Phil. 400, 400 (1998) ("over the last decade, proponents of deliberative democracy have moved...towards the very institutions they originally rejected as impossible locations for public reasoning").

5 Jürgen Habermas, Between Facts and Norms: Contributions to a Discourse Theory of Law and Democracy (William Rehg, trans. 1996); Iris Marion Young, Justice and the Politics of Difference (1990); Iris Marion Young, Inclusion and Democracy (2000).

${ }^{6}$ Young, Inclusion and Democracy, supra note 5; Henry S. Richardson, Democratic Autonomy: Public Reasoning about the Ends of Policy (2002); Joshua Cohen, Deliberation and Democratic Legitimacy, in The Good Polity: Normative Analysis of the State (Alan Hamlin and Philip Pettit, eds. 1989).

${ }^{7}$ John Rawls, The Idea of Public Reason Revisited, in John Rawls, The Law of Peoples (1999); Amy Gutmann and Dennis Thompson, Democracy and Disagreement (1996); Richardson, Democratic Autonomy, supra note 6.

${ }^{8}$ David Estlund, Beyond Fairness and Deliberation: The Epistemic Dimension of Democratic Authority, in Deliberative
An especially heavy burden falls on citizens, at least when they are engaged self-consciously in politics, for theories of deliberative democracy typically require citizens ideally to approach their deliberations with an almost heroic degree of sincerity, openness, impartiality, tolerance, persistence, and enthusiasm. Citizens engaged in democratic deliberation must, for example, treat each other with mutual respect and civility. ${ }^{7}$ They must work sincerely and cooperatively toward determining the truth. ${ }^{8}$ They must remain open-minded and receptive toward views and perspectives expressed by others. ${ }^{9}$ They must support any argument or position they advance with reasons, and in justifying their positions must confine themselves to invoking "public reasons," meaning reasons that all other reasonable citizens might in principle accept. ${ }^{10}$ And they must strive in deliberation to transcend disagreement by persuading others, rather than attempting to finesse disagreement through strategic bargaining, ${ }^{11}$ or even worse by overriding disagreement through raw exercises of the power of numerical superiority. ${ }^{12}$ Finally,

Democracy: Essays on Reason and Politics (James Bohman and William Rehg, eds. 1997); Gerald F. Gaus, Reason, Justification, and Consensus: Why Democracy Can't Have It All, in Deliberative Democracy: Essays on Reason and Politics, supra; Cohen, Deliberation and Democratic Legitimacy, supra note 6.

${ }^{9}$ Young, Inclusion and Democracy, supra note 5; Gutmann and Thompson, Democracy and Disagreement, supra note 7; Richardson, Democratic Autonomy, supra note 6; Melissa S. Williams, Voice, Trust and Memory: Marginalized Groups and the Failings of Liberal Representation (1998).

${ }^{10}$ Rawls, supra note 7; Joshua Cohen, Democracy and Liberty, supra note 2; Joshua Cohen, Procedure and Substance in Deliberative Democracy, in Democracy and Difference: Contesting the Boundaries of the Political (Seyla Benhabib, ed. 1996); Thompson, supra note 2, at 191; but see John S. Dryzek, Deliberative Democracy and Beyond: Liberals, Critics, Contestations 1-2 (2000). Bohman and Richardson have recently argued for the abandonment of the concept of reasons that all can accept. James Bohman and Henry S. Richardson, Liberalism, Deliberative Democracy, and "Reasons that All Can Accept," 17 J. Pol. Phil. 253 (2009).

${ }^{11}$ Cass R. Sunstein, Democracy and the Problem of Free Speech 72 (1993); Thomas Christiano, The Rule of the Many: Fundamental Issues in Democratic Theory 117 (1996); Bernard Manin, The Principles of Representative Government 198201 (1997).

${ }^{12}$ Young, Inclusion and Democracy, supra note 5; Manin, The Principles of Representative Government, supra note 11; Richardson, Democracy Autonomy, supra note 6; Cohen, Deliberation and Democratic Legitimacy, in The Good Polity: Normative Analysis of the State (Alan Hamlin and Philip Pettit, eds. 1989). 
throughout the deliberative process, the ideal to which participants ought to aspire is consensus; ${ }^{13}$ indeed, the ideal form of consensus is one based on agreement not merely as to the course of action to be taken, but as to the underlying reasons for taking it. ${ }^{14}$

All of these requirements share a clear purpose: to de-privilege majorities, and in so doing, to privilege minorities-or perhaps more accurately, to elevate minorities to a status of rough equality with majorities, thereby stripping majorities of the advantages they inherently enjoy in a democratic society. ${ }^{15}$ Majorities, after all, are not at risk in rough-and-tumble or strategically oriented politics; minorities are. Majorities are not disadvantaged by closed-mindedness, incivility, uncooperativeness, power plays, or instrumental bargaining, practices said to impede fair and productive deliberation; minorities are the ones who stand to suffer from these practices. Majorities have little to gain from deliberation, except perhaps in the thin, Millian sense of gaining a more vivid realization of the truth of their positions, ${ }^{16}$ if they are true. Majorities benefit not from talk, but from voting, and the sooner the better.

Majorities, moreover, have little to gain from deliberation among themselves. There is no compelling reason for people who already agree with one another to deliberate about their beliefs, and there are good reasons to fear that deliberation among the like-minded might actually make things worse, such as by creating the conditions for a selfconfirming opinion cascade that moves majority opinion to a more extreme version of its pre-deliberation formulation. ${ }^{17}$

Finally, majorities certainly have little to gain from pursuing an aspirational goal of consensus. Majorities stand to gain from practices that allow them, as soon as they coalesce, to trade their numerical superiority for control of government institutions. Minorities are the ones who stand to gain from a consensus requirement, whether binding or aspirational. Even if such a requirement is not strong enough to give minorities a veto, it is strong enough to enable them to demand, and perhaps to receive, the majority's attention, and with it the possibility of appealing to and persuading the majority to a different position-a possibility that, under deliberative democracy's rules, is meant to persist even after the minority has failed to prevent the majority from coalescing in the first instance.
Clearly, whatever is valuable about deliberation is realized only, or at least mainly, in one of two circumstances: when there is no majority, or when majorities deliberate with others who do not share their views - that is, with minorities. In the first case, the ground rules of sound democratic deliberation give each minority in principle an equal chance to persuade other minorities to their view. In the second case, the rules of deliberation offer minorities in principle an opportunity to persuade the majority to change its mind or to modify its position in a direction favored by the minority.

To a great extent, deliberative democracy's aversion to majorities is rooted in an unusually strong principle of equality. Democracy has often been said to proceed from a presumption of the equality of persons, ${ }^{18}$ but in most versions of democracy simple majority rule is accepted as a decision rule on the ground that it respects the moral worth of

${ }^{13}$ Joshua Cohen, for example, states unequivocally that the purpose of deliberation is "to arrive at a rationally motivated consensus." Cohen, Deliberation and Democratic Legitimacy, supra note 12, at 23. For Cass Sunstein, consensus is a "regulative ideal" governing the entire process of deliberative democracy. Cass R. Sunstein, The Partial Constitution 137 (1993). It is "the gold standard of political justification,...for deliberative democrats.” John S. Dryzek and Simon Niemeyer, Reconciling Pluralism and Consensus as Political Ideals, 50 Am. J. Pol. Sci. 634, 634 (2006).

14 "In the classic ideal, individuals enter a deliberation with conflicting opinions about what is good for the polity, but after voicing and hearing the reasons for different opinions, converge on one option as the best, for the same reasons." Jane Mansbridge with James Bohman, Simone Chambers, David Estlund, Andreas Follesdal, Archon Fung, Cristina LaFont, Bernard Manin, and José Luis Martí, The Place of Self-Interest and the Role of Power in Deliberative Democracy, 64 J. Pol. Phil. 64, 66 (2010); Alfred Moore and Kieran O'Doherty, Deliberative Voting: Operationalizing Consensus in a Deliberative Minipublic, Paper prepared for presentation at APSA Annual Meeting, August 30-September 2, 2012, at 5-6.

${ }^{15}$ Compare Frank I. Michelman, Can the People Ever Make the Laws? A Critique of Deliberative Democracy, in Deliberative Democracy: Essays on Reason and Politics (James Bohman and William Rehg, eds. 1997), at 152 (deliberative democracy "subordinates any and all pursuit of a social or collective good to a prior distributive constraint of right, of doing justice to each taken severally of as many as there are to be considered of the 'self-authenticating sources of claims'...that it recognizes") (quoting John Rawls, Political Liberalism 32 (1993)).

${ }^{16}$ John Stuart Mill, On Liberty 97-103 (Penguin ed. 1974) (1st ed. 1859).

${ }^{17}$ Cass R. Sunstein, Deliberative Trouble? Why Groups Go to Extremes, 110 Yale L.J. 110 (2000).

${ }^{18}$ Robert A. Dahl, Democracy and Its Critics ch. 7 (1989); Fishkin, supra note 3 , at 34; William N. Nelson, On Justifying Democracy 20 (1980); Richardson, supra note 6, at 28. 
each individual by applying a fair and impartial rule of aggregation. ${ }^{19}$ Deliberative democracy, though, goes further. In its strong form, "free deliberation among equals is the basis of legitimacy," 20 and participants do not consider themselves bound by a legal system "except insofar as that system establishes the framework of free deliberation among equals." 21 As a result, a legitimately binding expression of popular will cannot be constructed through the application of an externally derived decision rule, no matter how impartial and respectful it may be. Instead, equality requires that decisions actually be made by citizens themselves, in the inherently equality-respecting free play of deliberation, without resort to rules imposed on the deliberative process from outside it. Only in this way can democratic collective decisions "trace to the reasoning of the equals who are subject to the decisions." ${ }^{22}$ Indeed, deliberative democrats have long considered majority rule a form not of decision, but of coercion, on the ground that it proceeds not by force of the better reason, but by the force of the greater number. ${ }^{23}$

Deliberative democracy, then, aims to strip majorities of the advantages that, in politics, ordinarily inhere in numbers. ${ }^{24}$ It throws obstacle after obstacle in the path lying between majorities and the exercise of power. Suppose a majority of citizens comes to agreement on some point. May they now stop thinking about it and turn their attention to other problems? No; if a minority still wishes to discuss the matter, the majority must listen to the minority's views and reasons. ${ }^{25}$ May the majority listen with one ear for the sake of politeness while their minds wander to other topics? No, they must give their full attention. May they listen insincerely for the sole purpose of providing the minority with a superficially respectful hearing? No, they must remain genuinely open to persuasion by the force of reason.

Why does deliberative democracy insist on these demanding protocols? The answer seems to be that deliberation, for its proponents, offers an enticing prospect of change; it is capable of providing, they believe, a destabilizing shock to majoritarian political opinion, and thus to the status quo. The prescription for accomplishing this shock is simple: citizens must work hard to detach themselves intellectually and emotionally from what they already think they know and believe. In deliberation, all beliefs must therefore be deemed provisional, and must be checked and rechecked against any newly available information and arguments.

This self-detachment, deliberative democrats seems to believe, is the gate to the citadel of entrenched majoritarian opinion through which alternative, minoritarian ideas may just possibly enter. Thus, according to Henry Richardson, many deliberative democrats "would like to see reforms that more truly realize equality by empowering the weak and unsettling the status quo." ${ }^{26}$ In a recent manifesto, a group of nine leading theorists led by Jane Mansbridge states bluntly: "Transformations of preferences, and even on rare occasions 19 Elaine Spitz, Majority Rule xiii, 30 (1984); Jane Mansbridge,
Using Power/Fighting Power: The Polity, in Democracy and
Difference: Contesting the Boundaries of the Political 53
(Seyla Benhabib, ed. 1996).
${ }^{20}$ Joshua Cohen, Deliberation and Democratic Legitimacy,
supra note 12, at 21.
${ }^{21}$ Joshua Cohen, Democracy and Liberty, supra note 2, at 194.
${ }^{22}$ Joshua Cohen, Deliberative Democracy, in Deliberation, Par-
ticipation and Democracy: Can the People Govern? 220 (Shawn
W. Rosenberg, ed. 2007). Cohen continues: "the point of delib-
erative democracy is to subject the exercise of collective power
to reason's discipline,...not the advantage of the better situ-
ated." Id. He even goes further, arguing that the requirement
of equality in deliberation means that "those subject to the deci-
sions are treated as equals by the processes of making the deci-
sions, including agenda-setting and preference formation." Id.
Thus, majorities are not entitled to any special consideration
even in setting the ground rules of deliberation.

${ }^{23}$ Mansbridge, et al., The Place of Self-Interest, supra note 14, at 84-86; Przeworski, supra note 1, at 142 . On the other hand, it is sometimes said that even coercive decision rules can be justified in the Rawlsian manner on the grounds that they either have been, or more commonly could have been, agreed to by reasonable people in a fair deliberative process. See, e.g., Jane Mansbridge, Using Power, supra note 19.

${ }^{24}$ In this respect, deliberative democracy's strong equality requirement is reminiscent of a tradition in Anglo-American thought that holds political organization itself to be inherently suspect, and often shows up in an expressed distaste for political parties. Nancy L. Rosenblum, On the Side of the Angels: An Appreciation of Parties and Partisanship (2010).

${ }^{25}$ It is generally recognized, however, that time pressures may require a decision before deliberation is complete, or even sufficient. E.g., Robert E. Goodin, Reflective Democracy 167 (2003) (we should "discuss while we can, vote when we must").

${ }^{26}$ Richardson, supra note 6, at 74. See also Andrew Knops, Delivering Deliberation's Emancipatory Potential, 34 Political Theory 594 (2006); Iris Marion Young, Inclusion and Democracy, supra note 5, at 6 (deliberative democracy implies inclusion and equality to increase "the likelihood that democratic decision-making processes will promote justice"); James Bohman, Public Deliberation: Pluralism, Complexity, and Democracy 29 (1996) (deliberative democracy involves "the participation of all citizens in decision making, widely dispersing power in society"). 
transformations of underlying identities, in the direction of the common good can be among the most valuable features of deliberation." 27 This is a remarkable contention-that deliberation has the potential to cause individuals not merely to change their opinions, but their very identities. Deliberation is thus the ultimate destabilization agent. It destabilizes the status quo by creating conditions that not only may unsettle the majority beliefs that undergird it, but at least on some occasions may transform the underlying identities of the individuals who comprise the majority so that they become people who no longer truly desire the status quo.

Deliberative democracy, in sum, is a project fundamentally concerned with destabilizing and transforming settled majorities, and the beliefs to which they adhere. Its priorities and recommendations thus aim to undermine the privilege that democratic processes ordinarily confer on majorities, and to substitute a set of procedures that give greater opportunities to minorities to be heard, to influence public opinion, and to have their ideas compete on an equal footing, on their merits, for dominance in the public sphere.

\section{ELECTION LAW'S PRIVILEGING OF MAJORITY OPINION}

Things could not be more different in the world of election law. Many institutions of American law, without question, have been designed for the purpose of protecting and privileging political minorities - separation of powers, federalism, bicameralism, the Senate, the filibuster, the Electoral College, the bill of rights, and so forth. Election law, however, is not among them. Perhaps uniquely among major American legal institutions, the body of law now on the books that structures and regulates elections and their associated campaigns instead systematically privileges majorities, magnifies their power, impedes the inclusion of minority views, and discourages deliberation. Its purpose is to narrow the range of political disagreement and to tabulate exogenously held public opinion for the purpose of identifying a majority that is entitled to rule. These strategies are deeply woven into the fabric of the enterprise. ${ }^{28}$

To be sure, one would never know this from the way the U.S. Supreme Court talks about election law. A rhetorical commitment to the importance of persuasion and deliberation in electoral campaigns thoroughly suffuses our legal institutions. The Court has explicitly elevated the process of persuasion in election campaigns to the status of constitutional doctrine: "The primary goal of all candidates," the Court has held, "is to carry on a successful campaign by communicating to the voters persuasive reasons for electing them." 29 "Competition in ideas and governmental policies," says the Court, "is at the core of our electoral process and of the First Amendment freedoms." ${ }^{30}$ For that reason, "the First Amendment...has its fullest and most urgent application precisely to the conduct of campaigns for political office." 31

On the face of it, this kind of emphatic commitment to free and open political expression suggests a constitutional regime of electoral politics that accords a central role in election campaigns to deliberation. Election campaigns, however, do not take place in the abstract world described by broad, cross-cutting constitutional principles; they take place in the real world of concrete legal and political institutions. An examination of the legal regimes shaping our actual electoral institutions reveals that they operate on a set of very different principles. In particular, much of the constitutional architecture structuring the electoral process is based not on a robust commitment to electoral

\footnotetext{
${ }^{27}$ Mansbridge, et al., The Place of Self-Interest, supra note 14, at 79; see also Susan C. Stokes, Pathologies of Deliberation, in Elster, supra note 1, at 134 ("Public communication may change not only preferences but indeed identity").

${ }^{28}$ The same, I hasten to add, cannot necessarily be said of the election law of other nations. Elsewhere, devices such as proportional representation, low electoral thresholds, representational quota systems, and the like, may function to give minorities a much more significant role than they are afforded under American election law, which remains in many respects an outlier.

${ }^{29}$ Buckley v. Valeo, 424 U.S. 1, 101 (1976) (per curiam).

${ }^{30}$ Williams v. Rhodes, 393 U.S. 23, 32 (1968).

${ }^{31}$ Monitor Patriot Co. v. Roy, 401 U.S. 265, 272 (1971). This conception is also present in judicial theories based, for example, on the ideology of the marketplace of ideas, which presupposes a meaningful competition among political ideas in which citizens choose among those ideas on the basis of their persuasiveness. See, e.g., Stanley Ingber, The Marketplace of Ideas: A Legitimizing Myth, 1984 Duke Law Journal 1; David A. Strauss, Persuasion, Autonomy, and Freedom of Expression, 91 Colum L. Rev. 334 (1991). It is equally present in the theory of the First Amendment, long associated with the philosopher Alexander Meiklejohn, that the primary purpose of free speech is to enable citizens of a democracy to govern themselves intelligently. Alexander Meiklejohn, Free Speech and Its Relation to Self-Government (1948).
} 
deliberation, but on its opposite-on the premise that very little of what we might think of as deliberation is to be expected in the electoral process. I shall illustrate this proposition by reference to four constitutional regimes that contribute significantly to the structure of contemporary American electoral politics: the rules by which candidates may earn a place on the ballot; the constitutional treatment of laws regulating the giving and spending of money in election campaigns; the federal system of public financing of presidential elections; and the associational rights of political parties.

\section{Ballot access}

An election ballot is in a sense just a piece of paper, yet laws regulating the production of the ballot are among the most significant in an electoral democracy. Although such laws do not on their face purport to regulate much more than the terms upon which candidates may have their names printed on the ballot, in practice they exert an extremely powerful influence on the course of election campaigns. Most obviously, laws regulating access to the official ballot play a crucial gatekeeping role by establishing the conditions under which potential candidates for public office may become actual candidates. Although nothing in principle prevents candidates who are not listed on the ballot from waging a kind of rump campaign aimed at drawing attention to themselves or the issues they advocate, a candidacy unconnected to a place on the ballot is a severely disadvantaged one that is unlikely to serve, in the Court's words, as "an effective platform for the expression of views on the issues of the day" 32 and a "rallying point for like-minded citizens." 33

If the goal of election law were to encourage the widest range of campaign deliberation, we might expect it, under constitutional compulsion, to take an inclusive approach that affords all views, and the candidates who advocate them, easy and generous access to the ballot. After all, the Court has noted, even losing candidacies have "contributed to [the public's] understanding of the issues;" 34 "Abolitionists, Progressives, and Populists have undeniably had influence, if not always electoral success." ${ }^{35}$ In fact, however, state ballot access laws have, with the Court's approval, generally taken precisely the opposite approach. The main concern of today's ballot access laws typically is not to create a campaign in which many candidates and many points of view compete for public approval, but rather to narrow the scope of campaign discourse by restricting ballot access to candidates who support positions that already command substantial support among the electorate before the campaign has even begun.

Today, most states regulate ballot access according to a simple principle: parties and candidates that, prior to campaigning for office, can demonstrate substantial existing support among the electorate are permitted a place on the ballot; parties and candidates that cannot demonstrate such support are excluded. Consider, for example, Connecticut's not atypical scheme of ballot access. Like many states, Connecticut distinguishes between a "major party" and a "minor party." A "major party" is any party whose candidate for governor at the last gubernatorial election polled at least twenty percent of the total votes cast, or whose members comprise at least twenty percent of the total number of voters who have registered as members of a political party. ${ }^{36} \mathrm{~A}$ "minor party" is any party whose candidate "for the office in question" received at least one percent of the total votes cast. ${ }^{37}$ Under the statute, candidates nominated by parties that have qualified as major or minor are listed automatically on the ballot. ${ }^{38}$ In contrast, candidates of parties that were not sufficiently popular at the most recent election to qualify as "minor," and candidates wishing to run as independents, must make a showing of current support by filing nominating petitions containing signatures equal to one percent of the number of votes cast at the preceding election for the office for which they are running, or 7,500, whichever is less. ${ }^{39}$ Connecticut's

\footnotetext{
${ }^{32}$ Anderson v. Celebrezze, 460 U.S. 780, 788 (1983).

${ }^{33}$ Id. See also Buckley, 424 U.S. at 101 ("qualifying for the ballot [is] a step that, with rare exceptions, is essential to successful effort").

${ }^{34}$ Anderson, 460 U.S. at 798.

${ }^{35}$ Illinois State Board of Elections, 440 U.S. at 185-86. See also Munro v. Socialist Workers Party, 479 U.S. 189, 200 (1986) (Marshall, J., dissenting) ("The minor party's often unconventional positions broaden political debate, expand the range of issues with which the electorate is concerned, and influence the positions of the majority, in some instances ultimately becoming majority positions").

${ }^{36}$ Conn. Gen. Stat. § 9-372(5).

${ }^{37}$ Id., $\S 9-372(6)$.

${ }^{38}$ Id., $\S 9-379$.

${ }^{39}$ Id., $\S 9-453$ d. Candidates nominated by major and minor parties are precluded from qualifying for the ballot by nominating petition. Id., § 9-453t.
} 
scheme thus makes ballot access contingent upon a showing of electoral support well before the commencement of the official campaign. ${ }^{40}$ In the case of major and minor party candidates, support is simply presumed on the basis of recent electoral performance. All other candidates must show substantial support by producing signed nominating petitions before being admitted to the ballot.

The burden of these ballot access requirements on third party and independent candidates should not be underestimated. To obtain signatures of even one percent of the electorate for statewide office can require, in large states, a heroic effort. In Florida, for example, until 1998 third party and independent candidates for governor had to obtain nearly two hundred thousand signatures, a burden no candidate ever successfully carried. ${ }^{41}$ Nominating signatures, moreover, are costly to obtain. Commercial signature-collection firms routinely charge more than one dollar per signature, ${ }^{42}$ meaning that small-party or independent candidates might conceivably exhaust a good portion of their campaign resources merely qualifying for the right to run, if indeed they have the resources to qualify at all.

The effect of these kinds of ballot access schemes is of course to make it extremely unlikely that any views will be presented to the electorate during the campaign that do not, prior to the campaign, already enjoy significant public support. The typical ballot access regime thus serves not as an initial move in a campaign-endogenous process of open debate by diverse candidates and their supporters, but as a first-pass method of narrowing the scope of discussion to those ideas that are already widely held.

Given the Court's strong rhetorical commitment to open ballot access as a means of encouraging campaign-endogenous opinion formation, one might expect the Court to take a dim view of these kinds of restrictions. It has not. To the contrary, the Court has never invalidated a ballot access restriction solely on the ground that it required an excessive showing of pre-campaign support. ${ }^{43}$ In fact, the Court has enthusiastically endorsed state ballot access laws that restrict ballot positions to candidates who are able to show a significant level of exogenous pre-campaign public support. The Court has been quite clear on this point: to admit to the ballot candidates who do not begin the campaign enjoying "a significant modicum" of public support would be to tolerate a kind of "ballot...clutter[]" 44 or "clogging of [the] election machinery" that would court "voter confusion" at best, ${ }^{45}$ and would at worst open the door to "unrestrained factionalism" 46 and even "chaos." 47 Indeed, the Court has gone further: routine ballot access restrictions are constitutional because "a State has an interest, if not a duty, to protect the integrity of its political processes from frivolous or fraudulent candidacies." 48 Candidates, then, who enter campaigns hoping actually to persuade voters to a position that they do not in large numbers already hold before the campaign begins therefore do not display the "seriousness" necessary to justify

${ }^{40}$ Nominating petitions must be filed no later than ninety days before election day. Id., $\S$ 9-453i. See also id. § 9-423(a) (establishing second Tuesday in August as last date for party primary elections).

${ }^{41}$ Richard Winger, Ballot Access: A Formidable Barrier to Fair Participation, May 17, 2005, < http://www.ballot-access.org/ winger/fbfp.html $>$. Florida substantially eased this requirement in 1998 after an initiative amendment to the Florida Constitution required equality of candidate ballot access. Richard Winger, How Many Parties Ought to Be on the Ballot?: An Analysis of Nader v. Keith, 5 Election L.J. 170, 177 n.55. (2006).

${ }^{42}$ In California initiative drives, the present going rate appears to be between one and two dollars per signature, e.g., John Marelius and Ed Mendel, "Governor's Backers, Foes Scramble to Make Ballot," San Diego Union-Tribune, Mar. 28, 2005, A-1 (reporting going rate of $\$ 1$ to $\$ 1.50$ per signature), but considerably higher figures have often been reported. See, e.g., Robert Salladay, Game of the Name Is Profit, Los Angeles Times, Apr. 20,2005 , B-1 (reporting expenditures of $\$ 1$ to $\$ 2$ per signature); John M. Hubbell and Lynda Gledhill, Petition Circulators Cleaning Up, San Francisco Chronicle, March 24, 2004, B3 (\$3 to $\$ 3.50$ per signature); George Skelton, Gov.'s Performance in Role of "Reformer" Seems a Little Strained, Los Angeles Times, March 14, 2005, B-3 (up to $\$ 10$ per signature). ${ }^{43}$ See Jenness v. Fortson, 403 U.S. 431 (1971) (upholding Georgia ballot access requirement that independents collect signatures equal to five percent of the total number of voters eligible to vote at the last election); Storer v. Brown, 415 U.S. 724 (1974) (upholding California ballot access requirement that independent candidates collect signatures equaling five percent of total votes cast in the preceding election, during a 24-day period, exclusively from registered voters who vote in a party primary); American Party of Texas v. White, 415 U.S. 767 (1974) (upholding Texas ballot access scheme imposing successively more onerous requirements on major parties, minor parties, non-minor parties, and independents); Munro v. Socialist Workers Party, 479 U.S. 189 (1986) (upholding ballot access requirement that minor party candidates receive at least one percent of the total votes cast in the primary to qualify for a ballot position).

${ }^{44}$ Munro, 479 U.S. at 196.

${ }^{45}$ Bullock, 405 U.S. at 145.

${ }^{46}$ Storer, 415 U.S. at 736.

${ }^{47}$ Id. at 730 .

${ }^{48}$ Bullock, 405 U.S. at 145. 
a place on the ballot; ${ }^{49}$ they are "spurious candidates" whom the state is justified in "weeding out." 50

The Court's decisions in these cases expose an interesting paradox. In deciding ballot access cases, the Court relies primarily on constitutional principles of equal protection and free speech, principles generally understood to exist for the benefit of minorities, not majorities. ${ }^{51}$ How can constitutional commitments that benefit minorities be deployed so as to validate the conferral of advantages on a majority? The answer appears to be that rights are just as available to majorities as to minorities, and when majorities are capable of benefitting from the invocation of a right they can sometimes use it more powerfully and to greater effect than minorities. ${ }^{52}$ An important difference between deliberative democracy and a rightsbased constitutional regime is that the former is structured so as to provide rights that can be used only and exclusively by minorities - the right to be heard, the right to command attention and respect, and so forth. But in the legal system generally, the invocation of rights cannot easily be restricted to their intended beneficiaries.

\section{Campaign finance and the First Amendment privilege for widely held ideas}

Because most public political speech in the United States is generated privately and disseminated with privately held resources, the institution of campaign speech is built on, and inevitably reproduces, underlying inequalities in the distribution of resources, biasing it in favor of the rich. ${ }^{53}$ What is less obvious is that the governing constitutional regime also has a distinctly majoritarian bias. In particular, the existing constitutional rules favor the harvesting of private financial resources in a way that consistently advantages front-running beliefs and opinions, which is to say, the opinions of majorities. By the same token, constitutional speech rules subject the opinions of minorities to serious and cumulating disadvantages as an election campaign proceeds.

The First Amendment, the Court has consistently maintained, "has its fullest and most urgent application precisely to the conduct of campaigns for political office," 54 and laws restricting or regulating campaign speech are therefore severely disfavored. When regulation is based on the content of the speech, such laws must satisfy the most demanding degree of judicial scrutiny, one that requires the government to demonstrate that the law is supported by a "compelling state interest, and that it is narrowly drawn to achieve that end." 55 Even laws that regulate only the time, place, and manner of political speech, rather than its content, face an elevated degree of judicial scrutiny. ${ }^{56}$

On its face, robust constitutional protection for the freedom of campaign speech is consistent with a deliberative politics, and in its campaign finance cases the Court has stressed the Constitution's commitment to "[d]iscussion of public issues and debate on the qualifications of candidates." ${ }^{57}$ The difficulty, however, is that in its pursuit of a largely unregulated arena of free campaign debate, the Court has taken constitutional rules protecting speech and applied them with equal force to the protection of expenditures of money used to purchase and disseminate speech. ${ }^{58}$

${ }^{49}$ Lubin, 415 U.S. at 715; see also id. at 718 (producing signed petitions is a way for a candidate to "demonstrate the "seriousness' of his candidacy").

${ }^{50}$ Bullock, 405 U.S. at 146 . The Court used virtually identical reasoning in upholding the decision of a public television station to exclude from a televised campaign debate among candidates for Congress all but the major party candidates. Arkansas Educational Television Comm'n v. Forbes, 523 U.S. 666 (1998).

${ }^{51}$ Generally speaking, the purpose of all individual rights is to protect individuals and minorities from majoritarian tyranny. The locus classicus of this view is probably Footnote 4 of Carolene Products, United States v. Carolene Products Co., 304 U.S. 144, 152 n.4 (1938).

${ }^{52}$ This may help explain why majorities that deploy rights in politics often are at pains to cast themselves as oppressed minorities - the hated rich, for example, or people holding "unpopular" views, a claim that often seems in fact to mean "unpopular with vocal liberal minorities."

${ }^{53}$ See, e.g., Jacob Rowbottom, Democracy Distorted (2010).

${ }^{54}$ Monitor Patriot Co. v. Roy, 401 U.S. 265, 272 (1971).

${ }^{55}$ Burson v. Freeman, 504 U.S. 191, 198 (1992), quoting Perry Ed. Assn. v. Perry Local Educators Assn., 460 U.S. 37, 45 (1983).

${ }^{56}$ The pertinent legal test can vary with the circumstances, but is often what the Court now refers to as "exacting scrutiny," which requires a "substantial relation" between the law and some "'sufficiently important' government interest." Citizens United v. FEC, 558 U.S. 310, 366-367 (2010), quoting Buckley v. Valeo, 424 U.S. 1, 64, 66 (1976) (per curiam).

${ }^{57}$ Buckley v. Valeo, 424 U.S. 1, 14 (1976) (per curiam). See also, e.g., Federal Election Comm'n v. Massachusetts Citizens for Life, Inc., 479 U.S. 238, 259 (1986) (the First Amendment is concerned to "ensure that competition among actors in the political arena is truly competition among ideas").

${ }^{58}$ Buckley, 424 U.S. 1 (1976) (per curiam); Citizens United v. FEC, 558 U.S. 310 (2010). 
Under the constitutional rules crafted by the Court, direct spending to promote ideas or candidates cannot be restricted. ${ }^{59}$ The reason, the Court has explained, is that "[a] restriction on the amount of money a person or group can spend on political communication during a campaign necessarily reduces the quantity of expression by restricting the number of issues discussed, the depth of their exploration, and the size of the audience reached"; ${ }^{60}$ such limits, that is, impair the quality of campaign deliberation. Contribution limitations, in contrast, are permitted for two reasons. First, the speaker's interest in contributions is less because contributions communicate only a limited message, namely one of support: "[t]he quantity of communication by the contributor does not increase perceptibly with the size of his contribution, since the expression rests solely on the undifferentiated, symbolic act of contributing." 61 Second, this relatively slight diminution in the quantity of electoral speech is justified by the government's interest in "limit[ing] the actuality and appearance of corruption resulting from large individual financial contributions." 62

This jurisprudence of campaign finance, then, is built around two fundamental assumptions. The first assumption is that a candidate's expenditure of money during an election campaign translates into votes. The assumed relationship is certainly rough, but it is also roughly linear: the more candidates spend, the more votes they are likely to get. ${ }^{63}$ It is this assumption that drives the Court's doctrinal commitment to the principle that campaign spending by candidates for elective office, or their supporters, cannot in any circumstances be limited.

The second assumption driving the Court's campaign finance jurisprudence is that a candidate's $r e$ ceipt of money during an election campaign reflects support for that candidate, and that this support indicates to some degree endorsement by contributors of the candidate's ideological and policy positions. As the Court has put it, "[a] contribution serves as a general expression of support for the candidate and his views." ${ }^{64}$ As with spending, the relation between contributions and support is assumed to be rough, but also linear: the more support candidates enjoy among the electorate the more contributions they will receive, and the more contributions they receive the more widespread we may assume their support to be.
These two assumptions-that campaign spending is correlated to votes and that campaign contributions are correlated to support-together presuppose, and work to institutionalize, a system of electoral politics in which election campaigns are unlikely to serve as occasions for the deliberative contemplation of minority opinion. Instead, election campaigns are much more likely to function in a way that simply identifies, and transforms into political authorization, the opinions that a majority of voters hold at the inception of the

${ }^{59}$ Buckley, 424 U.S. at 17-20, 39-59; Citizens United, 558 U.S. at 340-67.

${ }^{60}$ Buckley, 424 U.S. at 19. The Court reserved its greatest antipathy for the government's argument that spending limitations were justified by an interest in "equalizing the relative ability of individuals and groups to influence the outcome of elections," a concept the Court deemed "wholly foreign to the First Amendment." Id. at 48-49.

${ }^{61}$ Id. at $20-21$.

${ }^{62}$ Id. at 26. Because this justification sufficed, the Court had no occasion to consider the sufficiency of the government's equalization-of-influence rationale. Id. However, in Randall v. Sorrell, 548 U.S. 230 (2006), the Court for the first time acknowledged a lower boundary to permissible limits on financial contributions to candidates.

${ }^{63}$ See Randall v. Sorrell, in which stringent contribution limitations were invalidated partly on the ground that challengers would be unable to raise sufficient funds to mount effective challenges to incumbents, 548 U.S. at 261 (opinion of Breyer, J.) (such limits threaten to "inhibit effective advocacy"). The proposition that money attracts votes is a widely accepted, though often implicit, premise among political theorists, see, e.g., Rawls, supra note 7, at 360-61; Thompson, supra note 2, at 112-14 (2002); legal scholars, see, e.g., Sunstein, Democracy and the Problem of Free Speech, supra note 11, at 99; David A. Strauss, What is the Goal of Campaign Finance Reform?, 1995 U. Chi. Leg. F. 141; Richard Briffault, Public Funding and Democratic Elections, 148 U. Pa. L. Rev. 577 (1999); judges, see, e.g., J. Skelly Wright, Politics and the Constitution, 85 Yale L.J. 1001, 1004 (1976); Attorney General of Canada v. Harper, 2004 SCC 33 (upholding limits on independent political spending as equalizing political influence); and of course the members of Congress who enacted the Federal Election Campaign Act. See, e.g., H.R. Rep. No. 93-1239, Report of the Committee on House Administration, Federal Election Campaign Act Amendments of 1974, 93d Cong., 2d Sess. 3 (1974) ("Under the present law the impression persists that a candidate can buy an election by simply spending large sums in a campaign"). Political science research seems to support this unobjectionable proposition. See Rebecca Morton and Charles Cameron, Elections and the Theory of Campaign Contributions: A Survey and Critical Analysis, 4 Economics and Politics 79, 81 (1992) ("the massive quantities of monies gathered by candidates do seem to increase the probability of election of the receiving and spending candidates, incumbent or challenger"); Gary C. Jacobson, Measuring Spending Effects in U.S. House Elections, in Capturing Campaign Effects (Henry E. Brady and Richard Johnston, eds. 2006), at 212-13. ${ }^{64}$ Buckley, 424 U.S. at 21. 
campaign. In this system, political ideas that are the most popular and widely held before the campaign starts, and the candidates who espouse them, will begin with an enormous advantage - the pole position, so to speak.

Here is how it works. If money enables candidates to deliver campaign speech, then any contribution received by a candidate before or shortly after the inception of the official campaign must by definition be donated on the basis of a point of view that has been formulated before the commencement of the campaign. It follows that candidates who enter the campaign supporting positions that are the most popular before the campaign begins will have an initial advantage. At or before the campaign's inception, they will attract more donations than their opponents. They will then use this money to communicate ideas that already enjoy widespread support among the electorate. Such ideas will likely appeal to more voters than competing, less popular ideas advanced by other candidates, an effect that may be expected to elicit further rounds of financial contributions from likeminded supporters. This additional support will multiply the initial advantage these candidates already enjoy by allowing them to communicate their message more broadly and intensely. These further rounds of communication then produce further rounds of contributions, producing additional communication, and so on. ${ }^{65}$

On its own assumptions, then, the campaign finance system constituted by the Court's decisions is likely to operate more as a vehicle for flushing out and ratifying majority opinion than as a vehicle for the formulation of public opinion through reflection and deliberation during the campaign. Any candidate who attempts to promote minority political ideas through a process of exposure and debate during the campaign itself will start off at a great, and possibly insurmountable, disadvantage. The system is thus well-designed to identify and cumulatively build support for views already held by a majority, but poorly designed to promote open-minded deliberation and serious encounters, on an equal footing, between majority and minority views. Rather, the way in which money enters the system operates to replicate and reify financially the distribution of pre-campaign opinion among the electorate, and to hand to majorities the tools to solidify their front-running positions. $^{66}$

\section{Public financing of election campaigns}

It is often argued that public financing of elections offers a possible cure for the biases that inhere in the private financing of campaigns in a society characterized by inequality in the distribution of private resources. ${ }^{67}$ In the United States, that potential has gone unfulfilled. On the contrary, the structure of federal public financing law actually enhances the majoritarian bias of public opinion formation during campaigns by providing an extra boost to candidacies supported by political majorities.

In a series of statutes stretching back to 1966, Congress has provided for public financing of presidential election campaigns. ${ }^{68}$ The present statutory scheme of public financing and the Supreme Court's reasoning in upholding it bear striking similarities to the ballot access laws and cases described above. Under the law, candidates for president may receive public financing in amounts that differ depending upon the pre-campaign popularity of the political party of which the candidate is the nominee. For purposes of funding, a "major party" is one whose presidential candidate received at least twenty-five percent of the vote in the preceding presidential election; ${ }^{69}$ a "minor party" is a party whose presidential candidate received between five and twenty-five percent of the vote in the last

${ }^{65}$ Michael, J. Malbin, A Public Funding System in Jeopardy: Lessons from the Presidential Nomination Contest of 2004, 5 Election L. J. 2 (2006), argues that this phenomenon is made even worse by the front-loading of presidential primaries, which requires candidates to raise money extremely early in the campaign to have any chance of gaining the kind of public exposure and attention necessary to mount a successful campaign.

${ }^{66}$ This conclusion clearly holds for contributions to candidates, which are capped. A different spending mechanism-independent spending and post-Citizens United contributions to independent-expenditure political action committees (PACs) obviously opens a different prospect: the possibility that rich minorities will spend amounts far disproportionate to their numbers. Nevertheless, the point I am making concerns the structure and design premises of legal institutions, and even the Court surely would have to concede that this possibility is a perversion, not a fulfillment, of the legal structure of the institution of independent expenditures.

${ }^{67}$ See, e.g., Joel L. Fleischman and Pope McCorkle, Level-Up Rather Than Level-Down: Toward a New Theory of Campaign Finance Reform, 1 J.L. \& Pol. 211 (1984); Richard L. Hasen, Clipping Coupons for Democracy: An Egalitarian/Public Choice Defense of Campaign Finance Vouchers, 84 Calif. L. Rev. 1 (1996).

${ }^{68}$ This history is recounted briefly in Buckley, 424 U.S. at 85 and n.114.

${ }^{69} 26$ U.S.C. $\S 9002(6)$. 
presidential election; ${ }^{70}$ and a "new party" is any other political party. ${ }^{71}$

Under the statute, candidates nominated by a major party are eligible to receive for the general election the full amount of public funds to which the law entitles them. ${ }^{72}$ Minor party candidates, however, are not entitled to the full amount of public funds made available to candidates of the major parties; they are entitled instead only to a proportion of that amount corresponding to the ratio by which their party's candidate in the previous presidential election fell short of the average number of votes earned in that election by the candidates of the major parties. ${ }^{73}$ Candidates of new political parties get no public financing up front, but are entitled to a post-election disbursement of public funds in proportion to the number of votes they actually receive, provided they receive at least five percent of the total popular presidential vote. ${ }^{74}$ Candidates who run as independents, without the backing of any political party, even a new one, may not receive public financing. ${ }^{75}$

Under this scheme, then, public campaign funds are allocated on the basis of a candidate's estimated pre-campaign support, creating a significant bias in favor of candidates who support positions that are widely held before the campaign commences. Although the federal public financing scheme is thus similar to the typical ballot access law, in which ballot access becomes easier as a candidate's estimated pre-campaign support increases, candidates for president who support less popular views suffer under this scheme from multiple disadvantages. First, because their views are not already widely held before the campaign begins, they must advance their positions through actual campaign-endogenous persuasion, requiring them to work harder during the campaign to earn votes. Second, again because their views are not exogenously popular, they have greater difficulty securing public funding for their election campaigns. Third, because they will have fewer resources at the outset of the campaign than candidates who enter it supporting exogenously popular views, they will be unable to keep pace with their competitors' spending, a disadvantage that will likely cause them to fall even further behind in appealing successfully for votes. In short, the bias under this financing system in favor of exogenously popular political opinion is severe.

The Supreme Court has had no difficulty sustaining this method of public financing. As in the ballot access area, the Court has identified the campaignendogenous formation of public opinion through deliberation as the central value of concern: "Subtitle $\mathrm{H}$ [the public financing provision] is a congressional effort, not to abridge, restrict, or censor speech, but rather to use public money to facilitate and enlarge public discussion and participation in the electoral process, goals vital to a self-governing people." ${ }^{76}$ Nevertheless, the Court dismissed challenges to the financing scheme's differential treatment of major and minor party candidates in terms similar to those it has employed in the ballot access arena: "Congress' [sic] interest in not funding hopeless candidacies with large sums of public money...necessarily justifies the withholding of public assistance from candidates without significant public support." 77

\section{Party competition and association}

Every state by law has structured electoral competition in a way that steers it into the form of party competition. Parties enjoy numerous privileges not just of law, such as rights of ballot access and recruitment and registration of members and candidates, but of constitutionally protected association. The nature of party competition, however, tends to steer electoral discourse into patterns that discourage meaningful deliberation and to privilege views already held by large and dominant groups of the like-minded.

The principal constitutional protection for parties lies in the First Amendment right of expressive association, ${ }^{78}$ a right derived from the first-order

\footnotetext{
${ }^{70}$ Id., $§ 9002(7)$.

${ }^{71}$ Id., $§ 9002(8)$.

${ }^{72}$ Id., § 9004(a)(1). In 2012, this amount was $\$ 91.2$ million, $<$ http://fec.gov/ans/answers_public_funding.shtml\#howmuchmoneydotheyget $>$, though neither major-party candidate chose to accept public funding.

${ }^{73} 26$ U.S.C. $\S 9004(\mathrm{a})(2)(\mathrm{A})$.

${ }^{74}$ Id., $\S$ 9004(a)(3).

${ }^{75}$ Given the possibility of some reimbursement for new party candidates under $\S$ 9004(a)(3), functionally independent candidates have a strong financial incentive to organize a new party as a vehicle for their independent run.

${ }^{76}$ Buckley, 424 U.S. at 92-93.

${ }^{77}$ Id. at 96.

${ }^{78}$ The right to expressive association is distinct from what the Court has called the right of intimate association. The latter is based not on the First Amendment, but on conceptions of personal autonomy in the choice of friends and intimate associates that are rooted in substantive due process. See Roberts v. United States Jaycees, 468 U.S. 609, 617-19 (1984).
} 
right to speak on the ground that "[e]ffective advocacy of both public and private points of view, particularly controversial ones, is undeniably enhanced by group association." 79 A political party, in the Court's view, is a paradigm of an expressive association, ${ }^{80}$ and the Court has invoked the right of association on numerous occasions to invalidate government regulations to which parties have objected. ${ }^{81}$

The main benefit that parties derive from the right to expressive association is the ability to control the content of their public communications. As speakers, parties enjoy the same freedom from censorship and content regulation that individuals possess directly under the First Amendment's firstorder protection for freedom of speech. ${ }^{82}$ The second-order right of expressive association, however, provides parties with the ability to control the content of their speech in another way: by controlling their membership. ${ }^{83}$ Thus, parties not only can decide who is entitled to be a member, but also can decide, even over the objection of the state, who is eligible to participate in the party's selection of its candidates. ${ }^{84}$ On this view, a party must be able to control its membership in order effectively to control its speech because the presence within an organization of individuals who do not share a commitment to its goals and positions can contradict or undermine the organization's message. ${ }^{85}$

Party competition is often supposed to be an institution that promotes deliberative decision making among the electorate. General elections, on this view, may serve as occasions for the deliberative exchange by parties of opposing points of view. Within parties, primary elections may function as vehicles for intra-party deliberation during which party members may be exposed to positions that are minority views even within their own party. Yet, although these possibilities exist, the structure of actual constitutional rules tends to discourage political deliberation by and within parties in numerous ways.

First, under the existing rules, the basis for constitutional protection of party membership is not its propensity to promote deliberation, but its quality as an act of ideological affiliation. The act of joining a party is thus pushed into a pattern not of deliberative engagement with the party's membership, but of an ideological endorsement of the party's preexisting positions, based on their congeniality to the pre-affiliation views of the new mem- ber. As a result, parties grow not by persuading the undecided, but by accreting the like-minded. Moreover, because under state law voter registrations are generally fixed until altered by a later affirmative act of the voter, the law invites voters to view the act of partisan affiliation not as a form of ongoing deliberative engagement with fellow partisans, but as a rare event that occurs only once, at the inception of a citizen's political life, a practice that seems to discourage, or at least fails to encourage, regular reflection on political commitments.

Second, the constitutional right of party association gives parties the authority to exclude people of different views from the party. This reduces the possibility that minority opinions might gain a foothold within a party, and squelches the potential for internal deliberation based on a diversity of viewpoints. Thus, the range of views accessible to party members even were they inclined to deliberate, is artificially restricted to those with whom party members are likely already to agree; certainly this will be the case for the major, most politically salient issues, the very ones that are most likely to entice voters

\footnotetext{
${ }^{79}$ NAACP v. Alabama, 357 U.S. 449, 460 (1958).

${ }^{80}$ Norman v. Reed 502 U.S. 279, 288 (1992). Accord New York State Board of Elections v. Lopez Torres, 552 U.S. 196 (2008). ${ }^{81}$ E.g., Cousins v. Wigoda, 419 U.S. 477 (1974); Tashjian v. Republican Party, 479 U.S. 208 (1986); Eu v. San Francisco County Democratic Central Committee, 489 U.S. 214 (1989); California Democratic Party v. Jones, 530 U.S. 567 (2000).

${ }^{82} \mathrm{Eu}$ v. San Francisco County Democratic Cent. Comm., 489 U.S. 214 (1989).

${ }^{83}$ Democratic Party of United States v. Wisconsin, 450 U.S. 107, 122 (1981) ("the freedom to associate for the "common advancement of political beliefs' necessarily presupposes the freedom to identify the people who constitute the association, and to limit the association to those people only") (citation omitted). Parties cannot, however, exclude members on the basis of constitutionally prohibited criteria such as race. Smith v. Allwright, 321 U.S. 649 (1944).

${ }^{84}$ See Tashjian v. Republican Party, 479 U.S. 208 (1986); California Democratic Party v. Jones, 530 U.S. 567 (2000).

${ }^{85}$ This might occur when unwanted members deliver a contrarian message under the organizational banner, Hurley v. IrishAmerican Gay, Lesbian and Bisexual Group, 515 U.S. 557 (1995), or when their mere presence within the organization by itself delivers a message that conflicts with the one the organization wishes to send. Boy Scouts of America v. Dale, 530 U.S. 640 (2000). An especially cogent example of this is the 1992 decision of the Georgia Republican Party to forbid David Duke, a former leader of the Ku Klux Klan, from running in Georgia's Republican presidential primary, an act tantamount to expelling him from the state party. The Court of Appeals for the Eleventh Circuit sustained the party's action. Duke v. Cleland, 954 F.2d 1526 (11th Cir. 1992).
} 
to affiliate ideologically with a party in the first instance.

Finally, whatever their dispositions regarding internal deliberation and debate, parties have little incentive to adopt deliberative tactics or to engage minority views in their external communications. Given the brief period of a campaign, a party's main incentive is to mobilize its membership, something done by appealing to majoritarian, campaignexogenous beliefs, not through challenging ideological engagement. Furthermore, were parties to invite deliberation with non-members, their targets would necessarily consist mainly of members of other parties. But like members of the speaking party, members of the audience party also have previously made a standing decision to affiliate ideologically with their party; they have committed themselves, in other words, to an opposing set of views, and consume intraparty communication within the cocoon of a cadre of the like-minded. ${ }^{86}$ All this has a tendency to push party competition into the format of a sorting mechanism the main function of which is to match voters with candidates based on exogenously held beliefs.

\section{A more minority-friendly election law?}

As the foregoing review makes clear, election law proceeds from a very different set of premises than deliberative democracy. At virtually every step of the formal process-from securing a spot on the official ballot, through the campaign phase, to Election Day voting - the relevant law progressively narrows the field of choice, providing cumulative advantages to views and candidates backed by a majority, and imposing corresponding disadvantages on opinions and candidates preferred by minorities. The very telos of American election law is not to provide an opportunity for minorities to influence majority opinion, but quite the opposite: to identify as quickly and as accurately as possible the pre-election views of the majority, and to clear a path for that majority to assume the reins of power. ${ }^{87}$ For this reason alone, it is difficult to see how election law could accommodate the principal concerns of deliberative democracy without undergoing a thorough, disruptive, and highly improbable transformation. ${ }^{88}$

Moreover, it is not at all clear that the kinds of modifications to election law that would be necessary to afford minorities the kind of treatment advocated by theories of deliberative democracy (whatever they might be) would constitute an improvement. There is a reason why election law takes its current form: it performs the difficult and indispensable task of taking an accurate snapshot of public opinion at a particular moment. In fact, the kinds of issues that election law now struggles with most arduously are to a considerable extent related to the accuracy of the snapshot-voter identification, registration purges, partisan administration of electoral laws, and so forth. Just getting an accurate count turns out to be such an enormously difficult and socially contentious task that it is hard to think of minority- and deliberation-friendly reform as within the realm of the possible.

\section{A ROLE FOR DELIBERATIVE DEMOCRACY IN NON-ELECTORAL POLITICS}

If, as I have argued, the goals and methods of deliberative democracy and election law differ so fundamentally, are theories of deliberative democracy capable of offering any practical guidance for

${ }^{86}$ See, e.g., Robert Huckfeldt and John Sprague, Citizens, Politics, and Social Communication: Information and Influence in an Election Campaign (1995) (using social network theory to explain why most political contacts tend to reinforce rather than to challenge or undermine voters' existing beliefs).

${ }^{87}$ Oddly, the one apparent exception to the trend I have described - the Voting Rights Act (VRA) - in fact operates in a way that is largely consistent with the general pattern. The VRA polices electoral structures and practices for the purpose of ensuring that racial and language minorities are not deprived of political representation, but it has been deployed mainly to carve out domains of minority dominance in regions where minorities would otherwise be submerged. E.g., Thornburg v. Gingles, 478 U.S. 30 (1986). The VRA thus does not proceed by forcing majorities to deliberate with protected minorities. Instead, like other institutions of American law that protect minority political power, such as federalism and bicameralism, the VRA proceeds by creating a separate sphere of minority dominance and replicating within that domain all the majority-preferring institutions normally associated with election law. The VRA thus in a way does not so much break down majority privilege as transfer it to a local minority. This of course has long been a complaint leveled against the Act's focus on winning over participation. See, e.g., Kathryn Abrams, "Raising Politics Up": Minority Political Participation and Section 2 of the Voting Rights Act, 63 N.Y.U. L. Rev. 449, 452-453 (1988)

${ }^{88}$ As John Dryzek has observed, “[d]owngrading the centrality of voting would involve a substantial ontological shift in our basic conceptualization of democracy." John S. Dryzek, supra note 10 , at 47 . 
reforming the legal regime now structuring American political life? The answer, I think, is almost certainly yes, but the guidance is best directed to venues other than the formal electoral system. Without a doubt, elections and their associated campaigns furnish dramatic and engaging focal points to democratic politics-elections, after all, provide those theatrical moments when public opinion is transformed into power, and in which the great democratic drama of the peaceful handing over of power is actually performed. Yet it is a profound mistake reductively to equate politics and elections. In truth, elections constitute only a small piece of the fabric of democratic life. If deliberative democracy teaches us anything, it is that most of what counts as democratic politics occurs on a daily basis, in ordinary political life, outside the unusual and strangely ritualized sphere of the formally electoral. It is here, I want to suggest, in politics rather than in elections, that theories of deliberative democracy offer the prospect of greater traction, and where their commitment to the hearing of minority views offers the best opportunity to frame and guide genuinely useful change.

\section{Deliberative democracy as a theory of politics, not elections}

Deliberative democracy has little to say to election law because, unlike, say, theories of democratic representation, it is at bottom not a theory of elections but a theory of politics. Deliberative democracy concerns itself predominantly with the formation of the public will, but most deliberative theorists tend to acknowledge that the democratically relevant deliberative public will is not formulated suddenly, in any single event such as an election campaign, but through a slow, decentralized, disaggregated process that occurs in many places at many times.

Habermas's well-known model, for example, contemplates a two-stage process ${ }^{89}$ in which the deep, legitimating public will takes shape in "an open and inclusive network of overlapping, subcultural publics having fluid temporal, social, and substantive boundaries [that] together...form a "wild' complex that resists organization as a whole." 90 Only after its formulation in this chaotic arena does the public will eventually make its way into the formal setting of institutionalized democratic politics. ${ }^{91}$ Theorists who have considered more specifically what kinds of institutions are capable of contributing to this disaggregated process of public will-formation sometimes mention political parties, social movements, local neighborhoods, the workplace, coffeehouses, newspapers, and radio call-in shows. ${ }^{92}$ With the exception of political parties, none of these is linked in any formal way to electoral processes, and all can be expected to perform any functions that contribute to formation of the public will continuously, regardless of election cycles.

Similarly, deliberative democracy theorists typically deemphasize the role of elections in disciplining elected officials by envisioning mechanisms that steer elected officials toward compliance with the public will as they go about their business-by definition, between elections. Gutmann and Thompson, for example, approach the problem by expanding the traditional notion of what counts as legislative representation. "Deliberative democracy," they contend, "does not specify a single form of representation. It searches for modes of representation that support the give-and-take of serious and sustained moral argument within legislative bodies, between legislators and the citizens, and among citizens themselves."93 Gutmann and Thompson thus understand deliberative democracy to require "an ongoing process. Deliberation continues through stages, as officials present their proposals, citizens respond, officials revise, citizens react, and the stages recur," a process they call "the reiteration of deliberation." 94

An election, on this view, is merely one pointand a not very significant point, at that-in an ongoing conversation between and among the public and elected officials about what ought to be done. The

\footnotetext{
${ }^{89}$ See Joshua Cohen, Reflections on Habermas on Democracy, 12 Ratio Juris 385, 389 (1999).

${ }^{90}$ Habermas, supra note 5 , at 307 .

${ }^{91}$ Id., chs. 4, 7.

${ }^{92}$ Cohen, Deliberation and Democratic Legitimacy, supra note 12, at 31; Seyla Benhabib, Liberal Dialogue Versus a Critical Theory of Discursive Legitimation, in Liberalism and the Moral Life (Nancy L. Rosenblum, ed. 1989), at 73; Benjamin Barber, Strong Democracy: Participatory Politics for a New Age ch. 10 (1984); Richardson, supra note 6, at 93, 184.

${ }^{93}$ Gutmann and Thompson, supra note 7 , at 13 (emphasis added).

${ }^{94}$ Id. at 143 . Habermas conceives of a roughly analogous process in which a public will forms in an anarchic and uncontrollable informal sphere, is then given expression in procedurally formalized fora resulting eventually in state legislative and administrative actions, and then thereby recirculated into the informal sphere for contemplation and possible revision. Habermas, supra note 5 , chs. $4,7$.
} 
more important moments in this conversation occur not so much when candidates propose themselves for office as when officials propose specific policies and actions for actual implementation. These proposals then serve, much more efficiently and precisely than do election campaigns, to focus public attention and discussion on exactly what deliberative democracy conceives to be the really important question for public deliberation: what ought we to do? The public will, then, guides the legislative will mainly through ongoing policy consultation, not through episodic electoral disciplining.

The low relevance of elections and electoral campaigns to theories of deliberative democracy is nowhere more vividly revealed than in the work of those who focus on the practical implementation of deliberative democracy. Some scholars and activists have begun to turn increasingly to the question of how a regime of deliberative democracy might be implemented in the real world. This work typically ignores election campaigns as a potential forum for thick deliberation, bypassing them altogether in favor of emphasizing ways in which citizens might deliberatively exert direct influence on policy decisions made by governments that have already, so to speak, been installed. ${ }^{95}$ When those who work at implementing deliberative democracy talk enthusiastically about successful models, they talk about participatory budgeting in Porte Alegre, Brazil, or deliberative urban planning in Perth, Australia; ${ }^{96}$ they rarely talk about enhancing the deliberative quality of electoral campaigns. ${ }^{97}$ In sum, then, theories of deliberative democracy generally hold that the kind of deliberation necessary to legitimate state power occurs mainly outside of electoral institutions, in an informal public sphere rather than within the formal institutions of the electoral process.

\section{The stability of majority opinion during election campaigns}

I argued in Part II that the formal electoral arena provides an inhospitable environment for deliberative democracy because its institutions are founded on incompatible principles and assumptions. But there is another reason why the electoral arena is inhospitable to the goals of deliberative democracy: it is an environment hostile to the destabilization of majority political opinion. In fact, a wealth of social science research demonstrates that majority political opinion is extremely stable during election campaigns, and is therefore unlikely to be altered during that brief period by exposure to contrary views. If anything, election campaigns are more likely to ratify and reinforce majority opinion than to destabilize it.

It is impossible here to go into detail about the ways in which public political opinion is formulated, so I shall limit myself to a few salient points. ${ }^{98}$ First, voters are not blank slates at the

${ }^{95}$ See, e.g., Fishkin, supra note 3; Ethan Leib, Deliberative Democracy in America (2004), ch. 1; Archon Fung, Empowered Participation: Reinventing Urban Democracy (2006).

${ }^{96}$ Boaventura de Sousa Santos, Participatory Budgeting in Porto Alegre: Toward a Redistributive Democracy, 26 Politics and Society 461 (1998); Janette Hartz-Karp, A Case Study in Deliberative Democracy: Dialogue with the City, 1 J. Public Deliberation 1 (2005).

${ }^{97}$ The Deliberative Democracy Handbook: Strategies for Effective Civic Engagement in the Twenty-First Century (John Gastil and Peter Levine, eds. 2005) purports to be a comprehensive guide to the ground-level implementation of deliberative democracy. Yet of nineteen chapters, only two (chapters 4 and 18) deal at all with deliberation in the context of an election, and even these involve only very minimal changes from existing electoral procedures, such as having citizens instead of journalists ask questions of candidates at formal debates. In one example, such questions were put to candidates by students too young to vote. The most comprehensive work on implementing deliberative democracy, in other words, has almost nothing to say about how elections could be made more deliberative.

The most significant exception to this pattern is Ackerman and Fishkin's book, Deliberation Day, in which the authors propose a national holiday, dedicated to public deliberation, to be held two weeks before Election Day in presidential election years. Bruce Ackerman and James S. Fishkin, Deliberation Day 3 (2004). Even if an official Deliberation Day is a feasible way to improve the quality of electoral discourse, it does not necessarily follow that the event should be held during the campaign season. Indeed, the goals of Deliberation Day might be better promoted by holding it between elections, before any candidates have emerged. As indicated in Part II above, party selection procedures, ballot access laws, and campaign finance regulations will already have drastically narrowed the scope of views represented by the candidates to those that already command the broadest public support before Deliberation Day even gets underway. See also Chad Flanders, Deliberative Dilemmas: A Critique of Deliberation Day from the Perspective of Election Law, 23 J. Politics 147 (2007). And by the time Deliberation Day rolls around, the public may well have been exposed to a numbing deluge of low-quality discourse that might damage citizens' ability to deliberate impartially, openmindedly, and cooperatively. Gastil's proposal would deal with this problem by using a mix of advisory, legislative prioritization, and candidate evaluation juries. John Gastil, By Popular Demand: Revitalizing Representative Democracy through Deliberative Democracy (2000).

${ }^{98}$ The case is laid out in detail in James A. Gardner, What Are Campaigns For? The Role of Persuasion in Electoral Law and Politics (2009), ch. 3. 
beginning of a campaign. As Berelson, Lazarsfeld, and McPhee recognized in a classic study conducted a half century ago, "[t]he individual's vote is the product of a number of social conditions or influences: his socioeconomic and ethnic affiliations, his family tradition, his personal associations, his attitudes on the issues of the day, his membership in formal organizations." 99 As Zaller has more recently put the point: "Every opinion is a marriage of information and predisposition." 100 A voter's decision to support a specific candidate or policy, in other words, often represents the most recent stage in a lengthy and complex ongoing process that long precedes the onset of the particular election campaign providing the occasion for casting the vote in question. There is strong evidence, for example, that voters learn much of what they believe about politics in childhood and maintain those beliefs throughout their lives. ${ }^{101}$

Second, the political beliefs people bring to campaigns tend to be stable and self-reinforcing during campaigns. Attempts to persuade voters during election campaigns face extremely significant obstacles in the form of cognitive biases, information-processing strategies, and social dynamics that together work with exceptional power to stabilize individual beliefs. For example, a selective attention bias causes people to attend most carefully to information with which they are already familiar or with which they already agree, and to ignore unfamiliar or challenging information. ${ }^{102}$ An interpretational bias tends to cause people to misinterpret new information that challenges their beliefs in a way that renders the information more consistent with their existing beliefs than is actually the case. ${ }^{103}$ Attitude-inconsistent information that the voter actually manages to perceive and absorb is both more likely to be actively resisted, ${ }^{104}$ and less likely to be retained or to be accurately recalled as inconsistent. ${ }^{105}$

A variety of social reinforcement effects also stabilize political opinion during election campaigns. Even voters open to new information typically have little choice but to look for it within the bounds of their own social networks, where the information available to be found is already biased by the environmental setting, thereby causing perpetuation of any initial bias. The social environment, in other words, "tends to reproduce the existing distribution of opinion." ${ }^{106}$ Powerful social forces, moreover, typically cause individuals to collaborate, so to speak, in the construction of a social environment in which they are less rather than more likely to encounter political opinions that differ from their own. For example, members of the same social group tend to share political opinions, and members of a social group have more contact with each other than with members of other groups. ${ }^{107}$ Such contacts are therefore more likely to reinforce than to challenge existing beliefs.

Finally, commonplace information processing strategies tend to innoculate individuals against ready alteration of their existing views. In today's society, the main problem voters face is not typically a dearth of relevant information but an overabundance of it, $^{108}$ requiring even the most responsible and dedicated of voters to develop coping strategies. One such strategy is the "on-line" model of information processing. According to

${ }^{99}$ Bernard R. Berelson, Paul F. Lazarsfeld, and William N. McPhee, Voting: A Study of Opinion Formation in a Presidential Campaign 37 (1954).

${ }^{100}$ John Zaller, The Nature and Origins of Mass Opinion 6 (1992).

${ }^{101}$ Angus Campbell, Philip E. Converse, Warren E. Miller, and Donald E. Stokes, The American Voter 146-48 (1960); M. Kent Jennings and Richard G. Niemi, The Political Character of Adolescence: The Influence of Families and Schools 37-62 (1974); M. Kent Jennings and Richard G. Niemi, Generations and Politics: A Panel Study of Young Adults and Their Parents, 89-93, 152-56 37-62 (1981); William N. McPhee, Jack Ferguson, and Robert B. Smith, A Theory of Informal Social Influence, in Formal Theories of Mass Behavior 83 (William N. McPhee, ed. 1963); Michael A. Milburn, Persuasion and Politics: The Social Psychology of Public Opinion 37 (1991).

${ }^{102}$ Joanne M. Miller and Jon A. Krosnick, News Media Impact on the Ingredients of Presidential Evaluations: A Program of Research on the Priming Hypothesis, in Political Persuasion and Attitude Change (Diana C. Mutz, Paul M. Sniderman, and Richard A. Brody, eds. 1996), at 79; Herbert F. Weisberg and Steven H. Greene, The Political Psychology of Party Identification, in Electoral Democracy 104 (Michael B. MacKuen and George Rabinowitz, eds. 2003); Huckfeldt and Sprague, supra note 86, at 141-42; Robert Huckfeldt, et al., Ambiguity, Distorted Messages, and Nested Environmental Effects on Political Communication, 60 J. Politics 996 (1998).

${ }^{103}$ Samuel L. Popkin, The Reasoning Voter: Communication and Persuasion in Presidential Campaigns 38 (1991); Milburn, supra note 101, at 111.

${ }^{104}$ Charles S. Taber and Milton Lodge, Motivated Skepticism in the Evaluation of Political Beliefs, 50 Am. J. Pol. Sci. 755 (2006). ${ }^{105}$ Miller and Krosnick, supra note 102, at 79.

${ }^{106}$ Huckfeldt and Sprague, supra note 86, at 53. See also Diana C. Mutz, Hearing the Other Side: Deliberative versus Participatory Democracy (2006), ch. 2.

${ }^{107}$ Berelson, Lazarsfeld, and McPhee, supra note 99, at 73-74, 88-101.

${ }^{108}$ Bryan D. Jones, Reconceiving Decision-Making in Democratic Politics: Attention, Choice, and Public Policy 95 (1994). 
this model, voters do not collect "raw" information in a value-neutral form and keep it handy until some point when they consider all the data at once to see what conclusion on balance it supports. Instead, voters collect information bit by bit, evaluating each new item as soon as they encounter it in what amounts to a kind of "running tally" on the subject in question. ${ }^{109}$ As a result, unless new information is dramatically different from whatever the voter has learned in the past, the voter's political judgments are likely to be affected only marginally by each new item, and his or her judgment will be extremely stable over time. ${ }^{110}$

Although this strategy is cognitively efficient, it gives opinions a kind of inertia or staying power they might not have if voters made judgments by weighing all the relevant data at once during the campaign. As a result, any individual's opinion can in most cases be moved only slightly on the basis of one or a few new pieces of information, no matter how positive or negative. A really significant change in a voter's evaluation of a party, a candidate, or a policy can in general result only from a lengthy and highly consistent stream of information that is inconsistent overall with the voter's existing provisional judgment, something very unlikely to occur during the short period of an election campaign.

Another, closely related information-processing strategy is the well-known Downsian strategy of "rational ignorance." Because acquiring information sufficient to make an informed decision, Downs argued, can be costly in both time and money, a rational voter will make the investment in electoral information only when the expected benefits exceed the costs, which might be infrequent. ${ }^{111}$ Downs's prediction appears to be borne out by the evidence; certainly voters tend to be ignorant of electorally relevant facts. ${ }^{112}$

It is important to be clear here. The social science literature does not say that people never change their minds when confronted by political information and arguments. It does, however, make an extremely powerful case that people almost never change their beliefs and opinions to any significant degree during campaigns. ${ }^{113}$ It tends to show instead that in any given citizen's life the engaged, deliberatively reflective alteration of political opinion is unusual and infrequent, and that the norm is for political opinion to form early, to evolve very gradually, to be largely immune from significant, much less sudden and dramatic revision, and for campaigns to have at best very little role in the formation of public political opinion, either at the individual or collective levels.

\section{The formation of public political opinion outside campaigns}

The fact that public political opinion is unlikely to be moved during campaigns does not by any means imply that the political opinions of voters are permanently fixed and incapable of changethat we lack, in other words, a meaningful democratic politics. We have, it seems to me, a fairly robust democratic politics, but it does not occur mainly during campaigns. It occurs instead at other times, indeed at all times and in all places where citizens' talk and behavior may have relevance for the formation of political opinions, which is to say constantly, in the course of everyday life. ${ }^{114}$ The main effect, then, of campaigns and elections that stress mobilization over deliberation and privilege majority opinion over minority views, is not to destroy or to diminish democratic politics, but rather to shift their locus from the

\footnotetext{
${ }^{109}$ Id. at 149.

${ }^{110}$ Benjamin I. Page, and Robert Y. Shapiro, The Rational Public: Fifty Years of Trends in Americans' Policy Preferences 16 (1992).

${ }^{111}$ Anthony Downs, An Economic Theory of Democracy (1957).

${ }^{112}$ Campbell, et al., supra note 101; Eric R.A.N. Smith, The Unchanging American Voter (1989); Michael X. Delli Carpini and Scott Keeter, What American Know About Politics and Why It Matters (1996); Page and Shapiro, supra note 110, at 4-9.

${ }^{113}$ This is a position long associated in political science with the "minimal effects" thesis. See, e.g., Thomas M. Holbrook, Do Campaigns Matter? (1996); Steven E. Finkel, Reexamining the "Minimal Effects" Model in Recent Presidential Campaigns, 55 J. Politics 1 (1993). For an overview, see Gardner, supra note 98 , at 86-90, 106-13.

${ }^{114}$ Zaller, for example, argues that a voter's "predispositions are at least in part a distillation of a person's lifetime experiences, including childhood socialization and direct involvement with the raw ingredients of policy issues, such as earning a living, paying taxes, racial discrimination, and so forth." Zaller, supra note 100, at 23. See also Benjamin I. Page, Who Deliberates? Mass Media in Modern Democracy 6 (1996) (arguing that campaign information supplied by the media is "supplemented and amplified to varying degrees by personal experience and by conversations with friends, neighbors, and coworkers"); Popkin, supra note 103, at 22 (advancing a "by-product theory of political information: the information that people acquire to negotiate their daily lives is later applied to their political judgments and choices").
} 
tightly confined and comparatively well-regulated realm of the electoral to the dauntingly wider and far more unruly realm of the political.

The democratic politics in which public political opinion is primarily forged occurs mainly in civil society-not, or at least not especially or disproportionately, in the officially circumscribed electoral arena itself. ${ }^{115}$ Citizens obviously do attend to and absorb information and arguments that they will later use to fashion the political opinions that will guide their official electoral behavior, and they do so frequently, perhaps even continuously. But the venues in which they do so are to be found mainly among the organizations, associations, and personal relationships in which they move in their private, "nonelectoral" capacities, ${ }^{116}$ and as much at times when they are not consciously thinking about politics as when they are. ${ }^{117}$

Here, then, is where the principles of deliberative democracy may be most usefully deployed. The problem of majoritarian bias is not confined to elections and campaigns; it arises everywhere that political opinion forms. The communicative environment outside the electoral arena is plagued by worrisome inequalities and structural problems that may have important ramifications for the way democratic politics unfolds once it enters the more circumscribed phase of the official campaign. These inequalities and structural problems may well entrench predictable biases in the production of mass political opinion in the public sphere.

Consider, for example, inequality of access to communicative resources. Communication-not just for electoral purposes but for more broadly political ones-costs money. The forms of mass communication capable of reaching and influencing the widest audiences, such as movies and television, for example, are accessible only to the wealthiest individuals and corporations. Video communication may likewise be costly to produce and require technical expertise. Advertising in newspapers and magazines and conducting mass mailings are also prohibitively expensive for all but a few. The Internet reduces the costs of distribution, but not of production, ${ }^{118}$ and is at present a haphazard method of reaching an intended audience, except for those able to pay for placement in targeted venues.

The high cost of communication coupled with the inequitable distribution of communicative resources means, of course, that information available in the most readily accessible regions of the public communicative sphere is likely to be biased in favor of the views of the rich. Additionally, the structure of media advertising revenue, which places a premium on the delivery of a mass audience able to pay for products, creates structural incentives favoring the production of programming that appeals to majorities rather than minorities. ${ }^{119}$ If the political views and preferences of the rich and the poor, or of majorities and minorities, tend in the aggregate to differ on some issues, then the content of information and persuasive discourse generally available in the communicative sphere will be biased in favor of the substantive positions of the rich and of majorities on those topics.

Even among those who have the resources to make use of mass media, inequality of actual access to media can have a skewing effect on the content of public political discourse. One of the more disturbing trends in the mass media sector is the increasing concentration of ownership of media outlets. We might expect, of course, that any particular media outlet will exhibit some bias in favor of the views of its owners, but this problem might be ameliorated if ownership of media is widely dispersed. ${ }^{120}$ Yet control of mass media is anything but dispersed: today only five companies own most of the nation's newspapers, magazines, book publishers, motion picture studios, and television and radio stations. ${ }^{121}$

Deliberative democracy's concern that the views of minorities be heard and evaluated on their merits

\footnotetext{
${ }^{115}$ As Dennis Thompson has recently suggested, "Campaigns should be considered more a part of government than a part of politics that influences government." Dennis F. Thompson, Two Concepts of Corruption: Making Campaigns Safe for Democracy, 73 Geo. Wash. L. Rev. 1036, 1055 (2005).

${ }^{116}$ Nancy L. Rosenblum, Membership and Morals: The Personal Uses of Pluralism in America (1998); Freedom of Association (Amy Gutmann, ed. 1998).

${ }^{117}$ Sam Fleischacker, Insignificant Communities, in Freedom of Association, supra note 116, at 288, 293.

${ }^{118}$ C. Edwin Baker, Media Concentration and Democracy 101 (2007). Baker made this point in 2007, and it is possible that since then, in the emerging age of Twitter, the Internet also reduces the cost of production. On the other hand, production of this type is cheap only for people who have already made a substantial investment in a smart phone and a wireless contract. Scrawling a poster with a magic marker may still be cheaper, purely as a matter of production, though not, clearly, in terms of distribution.

${ }^{119}$ C. Edwin Baker, Media, Markets, and Democracy 90-91 (2002).

${ }^{120}$ Baker, Media Concentration and Democracy, supra note 118, ch. 1 .

${ }^{121}$ Ben Bagdikian, The New Media Monopoly 3 (2004).
} 
has potentially great purchase here. First, measures that might be infeasible to incorporate into the brief and tightly controlled arena of formal campaigns and elections might be much more feasible if couched as reforms to the sprawling and almost entirely unplanned sphere of daily politics. Efforts to promote structural reforms or institutional innovations to make everyday political discourse more egalitarian and to give greater voice to minorities might, to be sure, face sharp challenges, but such challenges would be the ordinary ones that confront any critical reform movement rather than the distinctive challenges that would arise from attempting to take on a specialized, tightly constructed legal regime deliberately designed to serve contrary purposes.

Second, and more importantly, reforms guided by theories of deliberative democracy would very likely do more good in the sphere of nonelectoral politics than in the realm of formal electoral institutions. As I suggested earlier, a principal goal of deliberative democracy is to destabilize majority opinion, and in so doing to make majorities more open to minority views on their merits, increasing the chance of their reception by the dominant majority. For a variety of reasons detailed above, this is an all but impossible task in the 60- or 90day period of a formal election campaign. And although it is a difficult task to accomplish at any time, in any setting, it is likely more feasible to accomplish if conceived as the goal of a longterm, permanent reorientation of public political opinion formation in the larger sphere of democratic politics.

More fundamentally, any progress favorable to deliberative democracy that might be achieved in the political sphere will necessarily manifest itself in the electoral sphere. A majority that is rendered more receptive to minority views in the formulation of its political opinions will by definition take those opinions into the electoral arena, where the extant institutional regime will record and translate them into electoral outcomes. The converse is less likely to be true. Although political opinions and election results are doubtless to some extent mutually constitutive, the goals of deliberative democracy would surely be less secure in a system that attempts to destabilize majority opinion during election campaigns but then remands it for long periods between elections to a civil political sphere that tends to privilege and reinforce it.

\section{CONCLUSION}

Deliberative democracy offers an exciting and attractive conception of collective democratic life, one well worth attending and aspiring to regardless of whether its ideals ultimately are fully attainable. The question I have raised here is a secondary one: to what venues of political life ought we devote efforts to realize deliberative democracy's goalsto create, in other words, an actual deliberative democracy?

Electoral politics is of course modern democracy's great, theatrical showplace, and might therefore seem logically to be the proper locus of the greatest efforts at reform. I have argued here against that conclusion. The extant regime of election law is built around the reinforcement and privileging of majority opinion, an institutional orientation directly antithetical to the goals and methods of deliberative democracy. The legal regime, moreover, is built that way for good reason: the periodic, accurate recording of majority opinion is an indispensable function of any democratic regime, and one that is by itself complex and difficult enough. It ought not to be saddled with additional goals derived from deliberative democracy such as privileging the views of minorities or destabilizing majority opinion. Elections ought not to be forums for the destabilization of majority opinion, but for its accurate identification and recording. Elections and election law are therefore best understood as institutional alternatives to democratic deliberation.

By the same token, attempts to shoehorn into the electoral arena reforms guided by deliberative democracy are likely to be ineffective. Election seasons are - and should be-brief. Ordinary and welldocumented characteristics of the way human beings form political opinions raise numerous obstacles to the deliberative destabilization of majority opinion during the brief period allowed to formal elections and their associated campaigns. Conversely, because most of the action in political opinion formation occurs outside the formal campaign, reforms aimed at airing minority views, destabilizing majority ones, and promoting deliberative reformulation of collective political opinion are far better addressed to the period between elections - to the realm, that is to say, of ordinary, daily politics. To the extent our ordinary politics can be made fairer, more open-minded and respectful, and more deliberative, those benefits will be 
reaped in the arena of electoral politics to the same extent as if it were so targeted. In sum, there appear to be significant advantages to focusing reform efforts on non-electoral politics, and no discernable disadvantages.

Finally, in some ways, American law seems to have made a choice. Its preferred strategy for protecting minorities is not primarily to structure electoral processes to be receptive to minority influence so much as to convert minorities into local majorities by partitioning the public. Through institutions such as federalism and bicameralism, American law empowers minorities not by guaranteeing that their voices be heard and attended to by majorities, but by creating sub-domains in which minorities can ignore one another while enjoying a kind of local majority privilege. Within those domains, election law serves as the vehicle for consolidating majoritarian power. Deliberative democracy thus takes up a venerable American project, but pursues it in domains of law that historically have been thought to serve other purposes, by other means. Judged against ideal theory, this approach may be inferior to the forging of the grand, polity-wide consensus to which deliberative democracy aspires, but it may nevertheless be a workable, second-best solution that gives minorities some of what they want without taking on long-established and apparently deeply held conceptions of the legitimate power of majorities.

Address correspondence to: James A. Gardner

SUNY Buffalo Law School 514 O'Brian Hall Buffalo, NY 14260

E-mail: jgard@buffalo.edu 